\title{
イオン蒸着法による立方晶窒化ほう素膜の作製†
}

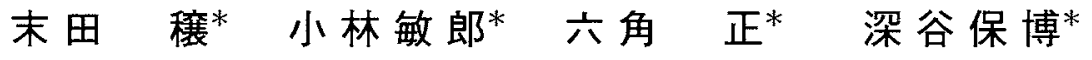 \\ 和田哲義** 山下信樹** 吉岡 肇*** 森本 聡*** \\ *三菱重工業株式会社広島研究所 \\ **三菱重工業株式会社基盤技術研究所 \\ ***三菱重工業侏式会社京都精機製作所
}

J. Japan Inst. Metals, Vol. 57, No. 8 (1993), pp. 932-937

\section{Formation of cBN Films by Ion Beam Assisted Deposition}

Minoru Sueda*, Toshiro Kobayashi*, Tadashi Rokkaku*, Yasuhiro Fukaya*, Tetsuyoshi Wada**, Nobuki Yamashita**, Hajime Yoshioka*** and Satoshi Morimoto***

\author{
*Hiroshima Research and Development Center, Mitsubishi Heavy Industries, Ltd., Hiroshima \\ **Advanced Technology Research Center, Mitsubishi Heavy Industries, Ltd., Yokohama \\ ***Kyoto Machinery Works, Mitsubishi Heavy Industries, Ltd., Kyoto
}

\begin{abstract}
Cubic boron nitride (cBN) has many excellent properties, such as the highest hardness next to diamond, high electrical insulation and high thermal conductivity. cBN films were deposited by IVD (Ion-beam-assisted vapor deposition) method. Effects of the ion current density, the composition of the supplied gas into the ion source and pressure in the vacuum chamber on $\mathrm{cBN}$ formation were investigated. At a constant $\mathrm{B}$ deposition rate, $\mathrm{cBN}$ was formed in a certain range of an ion current density. XPS analyses showed that the $c B N$ film has a stoichiometric composition of $\mathrm{BN}$, and the diffraction patterns from $\mathrm{cBN}$ (111), (220) and (311) were observed by transmission electron diffraction. Under the constant ion acceleration voltage and the $B$ deposition rate $\left(0.5 \mathrm{kV}, 0.13 \mathrm{~nm} \mathrm{~s}^{-1}\right)$, $\mathrm{cBN}$ was formed when an Ar-based gas containing $\mathrm{N}_{2}$ of 20 to $80 \%$ was supplied to the ion source. The deposition rate of cBN films was as high as about $5 \times 10^{-2} \mathrm{nms}^{-1}$ and the range of the $\mathrm{cBN}$ formation conditions was wide when the Ar-based gas contained $\mathrm{N}_{2}$ of 36 to $50 \%$. With increase of the pressure in the vacuum chamber, cBN formations were observed at lower ion current densities. We consider that this is due to the charge exchange and not only ions but accelerated fast neutrals also contribute to the cBN formation. Based on the above results, we propose a map of the cBN formation conditions as functions of fast $\mathrm{N}_{2}$ flux and fast $\mathrm{Ar}$ flux.
\end{abstract}

(Received February 9, 1993)

Keywords: ion-beam-assisted vapor deposition, cubic boron nitride, ion current density, ion acceleration voltage, boron deposition rate, charge exchange, fast neutrals, transmission electron microscopy, infrared absorption spectroscopy

\section{I ． 緒言}

閃(せん)覀鉛鉱型構造を持つ立方晶窒化注ら素 $(\mathrm{cBN})$ は天然 には存在しないセラミックス材料である。窒化ほら素(BN)の 結晶構造括よび特性は炭素のそれに類似している。cBNはダ イヤモンドに詨応している。本た，六方晶空化汪う素(hBN) はグラファイトに対応しており，軟質で閏滑性に富むといら性 質を有する。

cBNはダイヤモンドに次ぐ硬さを示し, 熱伝導性, 電気絶 縁珄にも優れている.さらに熱的, 化学的安定性机おいてはダ イヤモンドに勝り，特に鉄系材料以対して化学的煌めて安定 であるため,ダイヤモンドが鉄鋼材料の加工に適用し難いのに

$†$ 1991年10月日本金属学会秋期大会に和いて発表
対して, cBN は鉄鋼製品の奶削持よび研磨材料としても適し

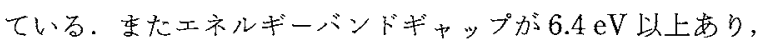
耐環境用半導体素子, 短波長光の固体発光素子への適用子注目 されている(1).

近年, 気相から $\mathrm{cBN}$ 皮膜在成膜する新しい方法が研究され ている.この研究に関しては，1980年に Weissmantel らは反 応性イオンプレーティング法により $\mathrm{cBN}$ 相を含さ $\mathrm{BN}$ 皮膜を 作製している(2)，承た，佐藤と藤本は $\mathrm{N}_{2}^{+}$イオン注入と质う素 の蒸着を同時に行らことにより, 数十 $\mu \mathrm{m} の \mathrm{cBN}$ の結晶粒を 含む BN 皮膜作製している(3)。こ机，イオンもしくは プラズマを用いた種々の方法に上り合成法の研究がなされて拉 り，たとえば，活性化ガスノズルを用いた反応性蒸着法(4)や反 応性 RF スパッタ法(5)，イオン蒸着法 ${ }^{(5)}$, プラズマ化学輸送 法(7)，タングステンフィラメントを用いた熱活性化 RF プラズ マ $\mathrm{CVD}$ 法 ${ }^{(8)}$ ，ECR プラズマ $\mathrm{CVD}$ 法(9)などが報告されてい 
る.しかし，手法によってはhBNとの混合相で cBN 単相が 得られなかったり，最適合成条件の把握や再現性等研究課題は 多くある.

著者らは既に，住う素蒸着と窒素，アルゴンイオン照射を併 用したIVD 法(Ion-beam-assisted vapor deposition method)K より BN 皮膜党作製し, 主にイオン加速電圧，活ら素供給速 度扣よびイオン入射角度の影響について検討し，適正な条件下 に执いて $\mathrm{Si}$ 基板上に $\mathrm{cBN}$ 皮膜が作製可能であることを確認し $た^{(10)-(12)}$.

本報では，IVD 法による $\mathrm{cBN}$ 生成条件範团に及活すイオン 電流密度, イオン源への供給ガス組成，真空槽内圧力の影響に つて詳細な検討を行った。

\section{II. 実験方法}

\section{1. 供試材料}

Table 1 亿供試材料を示す。蒸発材料は純度 99.9 mass\%の ほう素，イオン源への供給ガスは $99.999 \% \mathrm{Ar}$ と $99.999 \% \mathrm{~N}_{2}$ の混合ガス, 蒸着基板は $\mathrm{CZ}$ 法により作製された(111) 面, $\mathrm{N}$ 型の単結晶 Si ウェハーを $40 \%$ フッ酸で表面の酸化物を除去し たものを用いた。

\section{2. 成膜方法}

試験装置をFig. 1 亿示す，本装置は，真空槽，ターボ分子 ポンプ, Kaufman 型イオン源, 電子ビーム加熱式蒸発源, 水 冷した鉰製の基板ホルダー，フォラデーカップ，水晶発振式膜 厚モ二タ，イオン源朊よび真空槽へのガス供給・制御装置，電 離真空計より構成されている。本装置を用いて，Si 基板火対

Table 1 Material used.

\begin{tabular}{l|l}
\hline \hline Evaporating material & 99.9 mass\% Boron \\
\hline Gas & $\mathrm{Ar}+\mathrm{N}_{2}$ mixtures \\
\hline Substrate & Silicon wafer \\
& $\mathrm{CZ}, \mathrm{N}$-type (111) \\
\hline
\end{tabular}

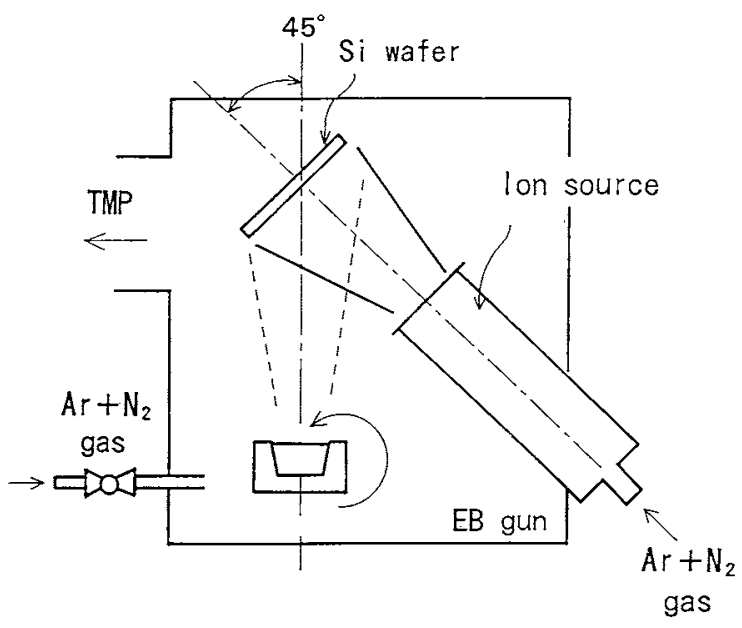

Fig. 1 Schematic diagram of the ion beam deposition apparatus.
してほう素を $\pi / 4 \mathrm{rad}$ の角度から蒸着しながら, イオンを垂直 以照射し，成獏した。

泀ら素供給速度はイオンビームの当たらない所に設置した水 晶発振式膜厚モ二タにより，イオン電流密度は基板ホルダーの 裹側に設置したファラデーカップを反転させ， $\mathrm{Si}$ 基板位置で の値を成膜の前後に測定した。ファラデーカップの2 次電子

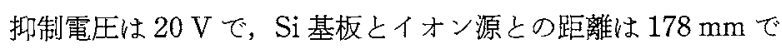
ある。

\section{3. 成膜条件}

成膜条件を Table 2 飞示す.イオン加速電圧の影響につい ては既に詳細に検討し(10)(11)，0.2〜2kVで $\mathrm{cBN}$ 相が合成でき ることを明らかとして拉り，本報では $0.5 \mathrm{kV}$ とた。汪ら素 の供給速度は $0.13 \mathrm{~nm} \mathrm{~s}^{-1}$ とて，イオン電流密度を変化させ その影響を調べた。

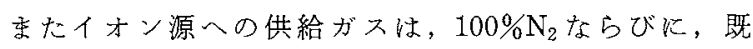
報(10)(11)で添加が $\mathrm{cBN}$ の合成に重要な役割をはたすことを報 告した $\mathrm{Ar}$ を種々の部合で混合した $\mathrm{N}_{2}$ を用い，供給がス組成 の影響を調べた。さらに，真空槽内の圧力の影響を調べるた め, 真空槽に，イオン源への供給ガスと同組成のガスを供給す ることにより真空槽内の圧力を変化させた。ここで真空槽内の 圧力は真空槽の側壁に設置した電離真空計により計測した。

\section{4. 皮膜の分析方法}

得られた皮膜の結晶構造の同定は主としてフーリエ変換赤外 分光(FT-IR)分析により行った。赤外分光スペクトルでは, cBNは 1000 $1100 \mathrm{~cm}^{-1}$ の間飞吸收帯が存在し, 一方, $\mathrm{hBN}$ は $1390 \mathrm{~cm}^{-1}$ K B-N 伸縮モードK対応する吸收と, 800 $\mathrm{cm}^{-1}$ にB-N-B 曲け゚モードに対応する吸收が存在する(13)(14)た め, Fig. 2 よら飞, ピーク高さの比 $I_{\mathrm{c}} /\left(I_{\mathrm{c}}+I_{\mathrm{h}}\right) よ り$ 定量 化 乙,$I_{\mathrm{c}} /\left(I_{\mathrm{c}}+I_{\mathrm{h}}\right)>0.65$ cBN 相, $0<I_{\mathrm{c}} /\left(I_{\mathrm{c}}+I_{\mathrm{h}}\right)<0.65$ を $\mathrm{cBN}$ と hBN の混在相, $I_{\mathrm{c}} /\left(I_{\mathrm{c}}+I_{\mathrm{h}}\right)=0$ をhBN 相と定義した。

また，得られた $\mathrm{cBN}$ 皮膜の構造を確認するために電子線回 折を行った。銅メッシュの試料台を皮膜に押しつけ，皮膜を $\mathrm{Si}$ 基板加剥離さ世，透過型電子影微鏡 (日立製 $\mathrm{H}-800 \mathrm{UHR}$ ) により加速電圧 $200 \mathrm{kV}$ で回折像を得た。

皮膜の組成はX 線光電子分光分析(XPS) と上り汪ら素之空 素の原子比を算出した. その際后ら素/窒素原子比=1の標準 サンプルとして熱分解窒素注ら素を用いた。

皮膜の厚さは，破断面の走查型電子顕微鏡(SEM) 写真より 測定した。

Table 2 Deposition conditions for BN films.

\begin{tabular}{l|l}
\hline \hline Ion acceleration voltage & $0.5 \mathrm{kV}$ \\
\hline Ion current density & $1 \sim 10 \mathrm{Am}^{-2}$ \\
\hline $\begin{array}{l}\text { Gas composition introduced to ion } \\
\text { source }\end{array}$ & $\mathrm{Ar}+0 \sim 100 \% \mathrm{~N}_{2}$ \\
\hline Boron deposition rate & $0.13 \mathrm{~nm} \mathrm{~s}^{-1}$ \\
\hline Operating pressure & $0.67 \sim 4.0 \times 10^{-2} \mathrm{~Pa}$ \\
\hline
\end{tabular}




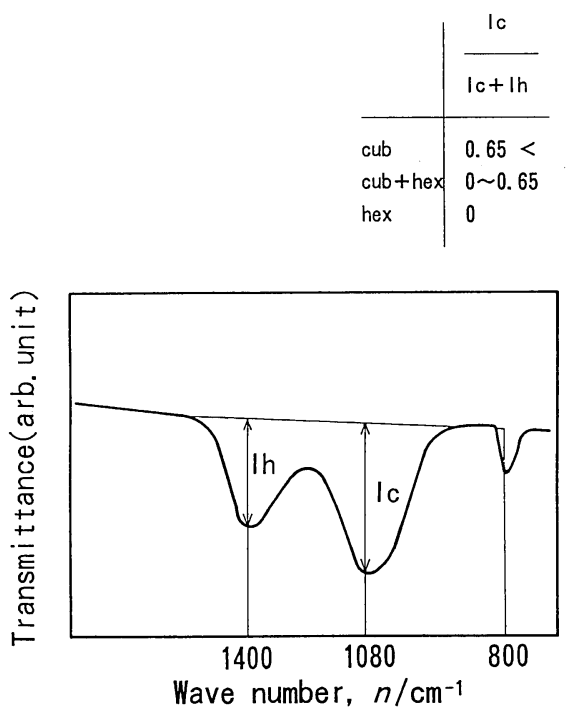

Fig. 2 Definition of the crystal systems for BN films from FT-IR spectra.

\section{III. 実 験 結 果}

\section{1. 結晶構造に及ぼすイオン電流密度の影響}

Fig. 3(a)にイオン源への供給ガス組成 $\mathrm{Ar}+36 \% \mathrm{~N}_{2}$ ，イオ ン加速電圧 $0.5 \mathrm{kV}$, 注ら素供給速度 $0.13 \mathrm{nms}^{-1}$, 真空槽内圧 力 $1.3 \times 10^{-2} \mathrm{~Pa}$ と一定とし, イオン電流密度を $2 \sim 7.5 \mathrm{Am}^{-2}$ と変化させて成膜した皮膜の赤外分光スペクトルを示す. これ より適正なイオン電流密度の範囲で $\mathrm{cBN}$ 相が生成し, イオン 電流密度が過㮃であるとェッチングされ皮膜が形成されないか, $\mathrm{hBN}$ 相あるいは $\mathrm{cBN}$ と $\mathrm{hBN}$ の混在相が生成することがわか る。また，イオン電流密度が不足すると $\mathrm{hBN}$ 相を示すが，さ らに不足すると $1400 \mathrm{~cm}^{-1}$ 付近の吸収がブロードとなり, N-

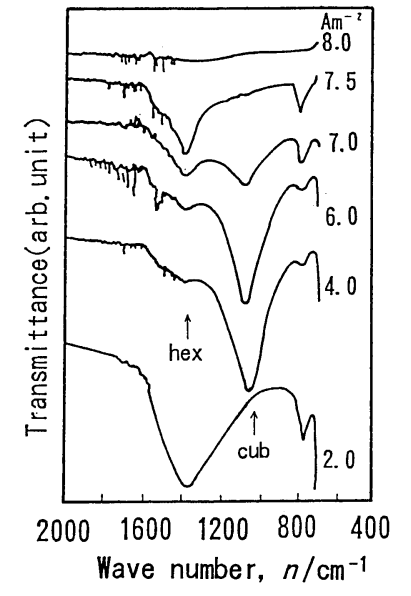

(a)

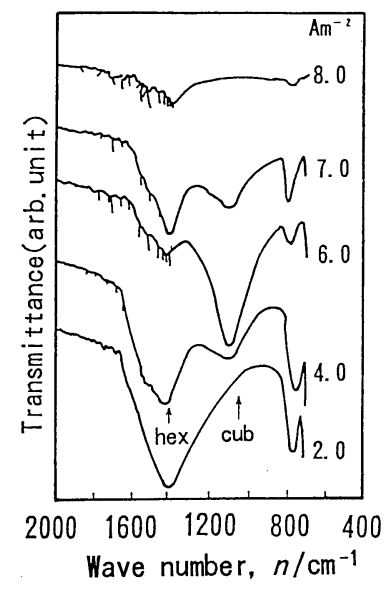

(b)
Fig. 3 FT-IR spectra of $\mathrm{BN}$ films deposited at various ion current density. (a) The gas composition was $\mathrm{Ar}+36 \% \mathrm{~N}_{2}$ and operating pressure was $1.3 \times 10^{-2} \mathrm{~Pa}$. (b) The gas composition was $\mathrm{Ar}+50 \% \mathrm{~N}_{2}$ and operating pressure was $1.3 \times 10^{-2} \mathrm{~Pa}$.
Table 3 Comparison of observed interplanar spacings with the reported values.

\begin{tabular}{c|c|c|r|r}
\hline \hline \multicolumn{2}{c|}{ Observed value } & \multicolumn{3}{c}{$\begin{array}{c}\text { JCPDS 25-1033 } \\
\text { zinc blende structure }\end{array}$} \\
\hline$d(\mathrm{~nm})$ & $I^{*}$ & $d(\mathrm{~nm})$ & $I / I_{1}$ & $(h k l)$ \\
\hline 0.210 & $\mathrm{VS}$ & 0.2088 & 100 & $(111)$ \\
$\ldots$ & $\ldots$ & 0.1808 & 2 & $(200)$ \\
0.129 & $\mathrm{~S}$ & 0.12785 & 6 & $(220)$ \\
0.111 & $\mathrm{~S}$ & 0.10901 & 3 & $(311)$ \\
\hline$*$
\end{tabular}

* VS : very strong, S : strong.

2 項で後述するように, XPS 分析結果から N/B 原子比 $<1$ の 量論比よりホウ素が過剩な窒化浮ら素皮膜となる.

Fig. 3(a)で得られた cBN 皮膜の電子線回折結果を Fig. 4 怙よび Table 3 に示す.cBN の (111) 面, (220) 面, (311) 面 での回折と考兄られるパターンが得られた．また透過型電子顕 微鏡の明視野像を Fig. 5 に示すが，まだら模様の大きさより 結晶粒径は約 $10 \mathrm{~nm}$ の微結晶から成る多結晶であることがわ かる.

Fig. 3(b)にイオン源への供給ガス組成を $\mathrm{Ar}+50 \% \mathrm{~N}_{2}$ とし， 他の条件はFig. 3(a)の場合と等しくして作製した皮膜の赤外 分光スペクトルを示す. Fig. 3(a)の $\mathrm{Ar}+36 \% \mathrm{~N}_{2}$ の場合と $\mathrm{cBN}$ 相の生成するイオン電流密度範囲は若干異なるが, 同様 の傾向を示すことがわかる.

\section{2. イオン源への供給ガス組成の影響}

III-1 項と同様に他のガス組成について検討した結果をまと めて Fig. 6(a)に示す.これより大別するとエッチングされ皮 膜の形成されない領域, $\mathrm{cBN}$ 生成領域, $\mathrm{hBN}$ 生成領域, それ らの間の $\mathrm{cBN}$ と $\mathrm{hBN}$ の混在する領域に分けられることがわ かる.

また, cBN 生成領域において, 各ガス組成で最大の成膜速

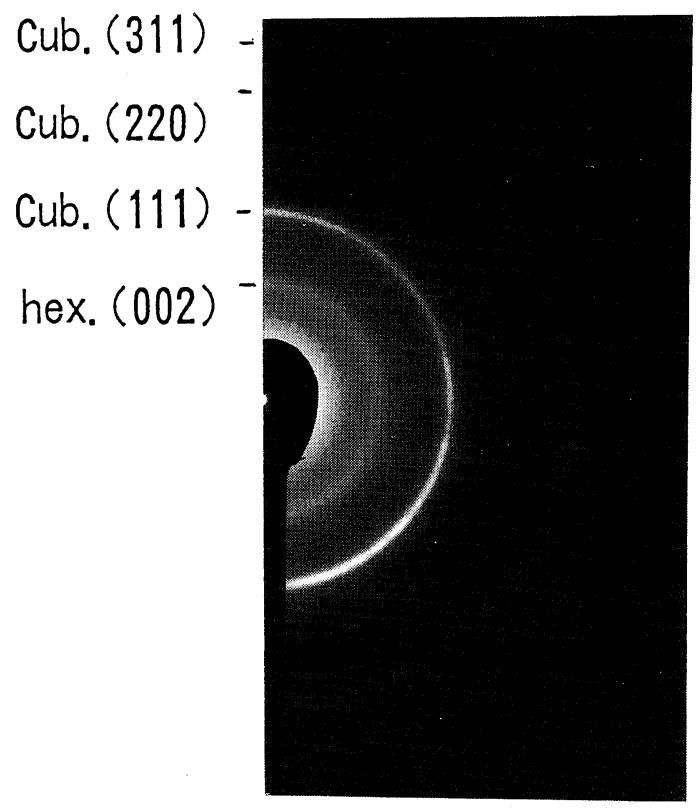

Fig. 4 Transmission electron diffraction pattern of the $\mathrm{cBN}$ film. 


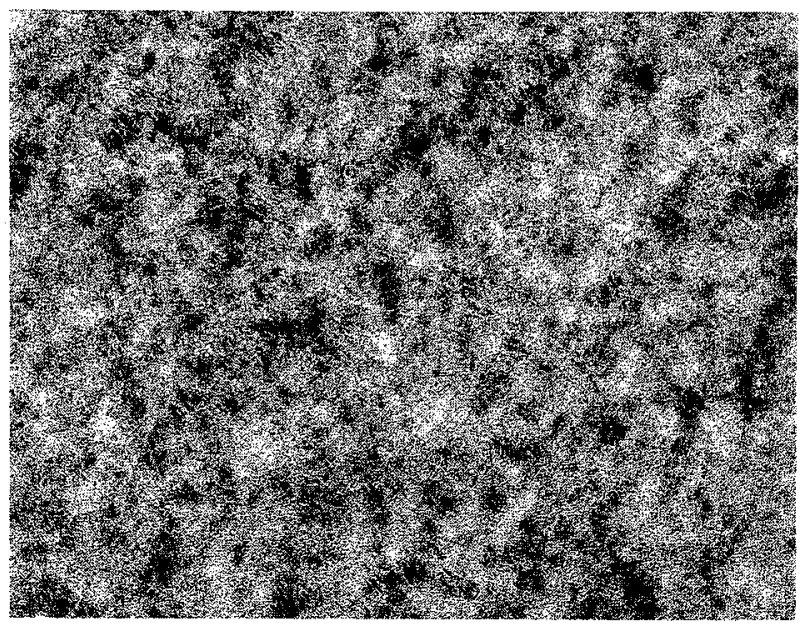

$100 \mathrm{~nm}$

Fig. 5 TEM bright field image of the cBN film.

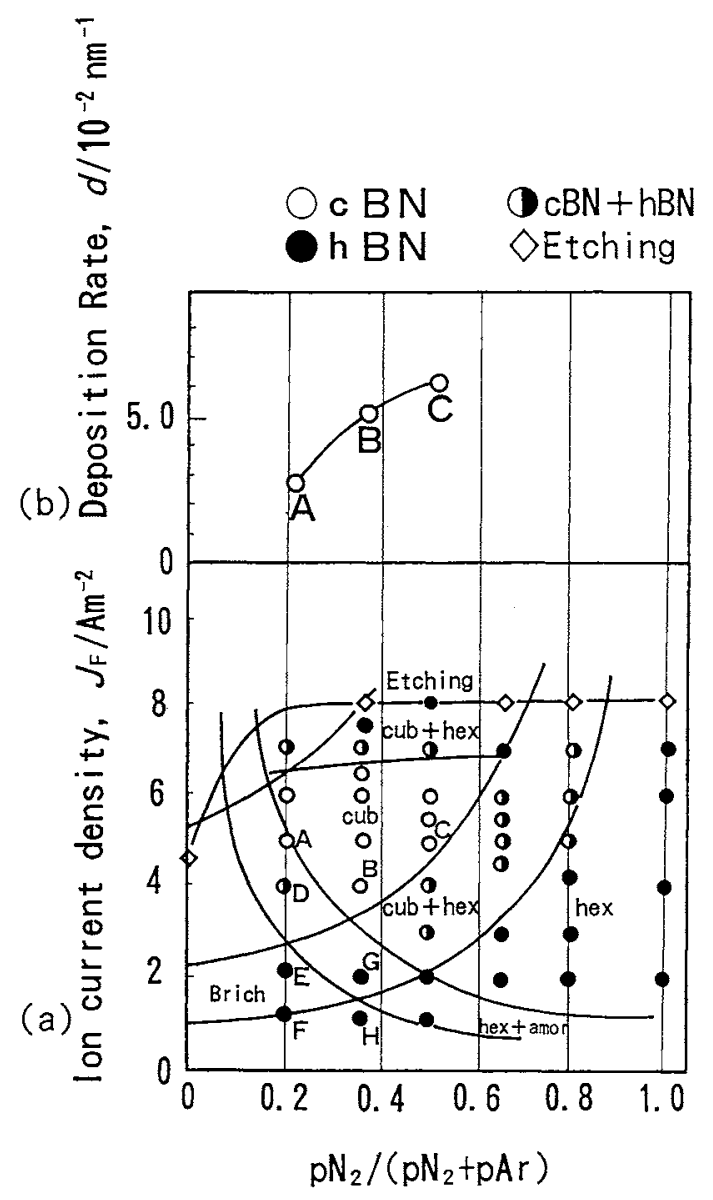

Fig. 6 Conditions for deposition of BN films. (a) Effects of $p \mathrm{~N}_{2} /\left(p \mathrm{~N}_{2}+p \mathrm{Ar}\right)$ and current density on the phases of BN films. (b) Effects of $p \mathrm{~N}_{2} /\left(p \mathrm{~N}_{2}+p \mathrm{Ar}\right)$ on the highest $\mathrm{cBN}$ deposition rate of $\mathrm{cBN}$ films.

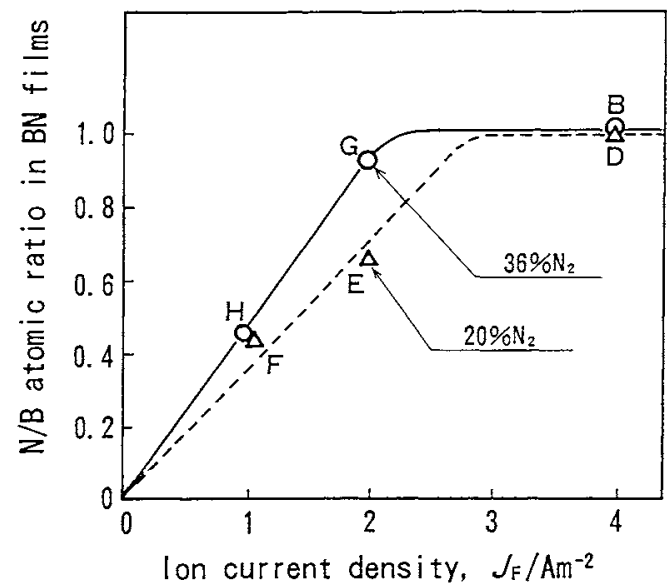

Fig. 7 Relation between N/B atomic ratio of the $\mathrm{BN}$ films measured by XPS and ion current density at $D \sim H$ in Fig. 6 operating pressure was $1.3 \times 10^{-2} \mathrm{~Pa}$.

度を示主条件 A, B , C Kついて成膜速度を調べると Fig. 6(b) のよ5《なり, 成膜速度, 生成条件範囲の観点から, $\mathrm{Ar}+20 \% \mathrm{~N}_{2}$ より, $\mathrm{Ar}+36 \% \mathrm{~N}_{2}, \mathrm{Ar}+50 \% \mathrm{~N}_{2}$ が適正であるこ とがかかる。

Fig. 6(a) 中の D H 点についてXPSにより N/B 原子比を 測定した結果を Fig. 7に示す。これより，注う素の供給速度 に対して，イオン電流密度が不足すると N/B 原子比く1の， 量論比より汪う素が過剩な窒化汪ら素皮膜となることがわか る。

\section{3. 真空槽内圧力の影響}

イオン源への供給ガス組成 $\mathrm{Ar}+36 \% \mathrm{~N}_{2}$ ，イオン加速電 压 $0.5 \mathrm{kV}$ ，潘う素供給速度 $0.13 \mathrm{~nm} \mathrm{~s}^{-1}$ と一定とし, $\mathrm{Ar}+$ $36 \% \mathrm{~N}_{2}$ ガスを導入することにより，真空槽内压力を 0.67 $4.0 \times 10^{-2} \mathrm{~Pa}$ と変化させた場合の結果を Fig. 8 に示す。いず れの圧力でる $\mathrm{cBN}$ の成膜が可能であり, イオン電流密度依存 性は同じ傾向を示す。

しかし，グラフの傾きは右下がりとなり，各相の生成条件範 囲は低電流密度側へシフトしている.この原因の1つとして, 真空槽内の圧力の增加伴い, 窒素分圧子増加し, この窒素に よる卧ら素の壁化の影響が考觉られるため，Arがスのみを真 空槽内に導入し， $3.7 \times 10^{-2} \mathrm{~Pa} し て$ 成膜したが， $\mathrm{Ar}+$ $36 \% \mathrm{~N}_{2}$ ガスを導入した場合と同結果となり, 真空槽内の䇪素 分压の影響ではないことが判明した。 その際，イオン源へ $\mathrm{Ar}+36 \% \mathrm{~N}_{2}$ 在 $6.7 \mathrm{~mm}^{3} \mathrm{~s}^{-1}$, 真空槽へ $\mathrm{Ar} 15.1 \mathrm{~mm}^{3} \mathrm{~s}^{-1}$ 供 給しており, 定常状態では真空槽内のガス組成は $\mathrm{Ar}+11 \% \mathrm{~N}_{2}$ となっているものと考充られる. その他の原因として荷電変換 が挙げられ，これについては，N-1 項で考察を加兑る.

\section{N. 考察}

\section{1. 真空槽内圧力の影響}

III-3 項の結果, 真空槽内圧力が高くなるに従い，各相の生 成条件範囲が低電流密度側ヘシフトしたが，これは真空槽内の 窒素分圧に依存するあのではないことがすかった。したがっ 


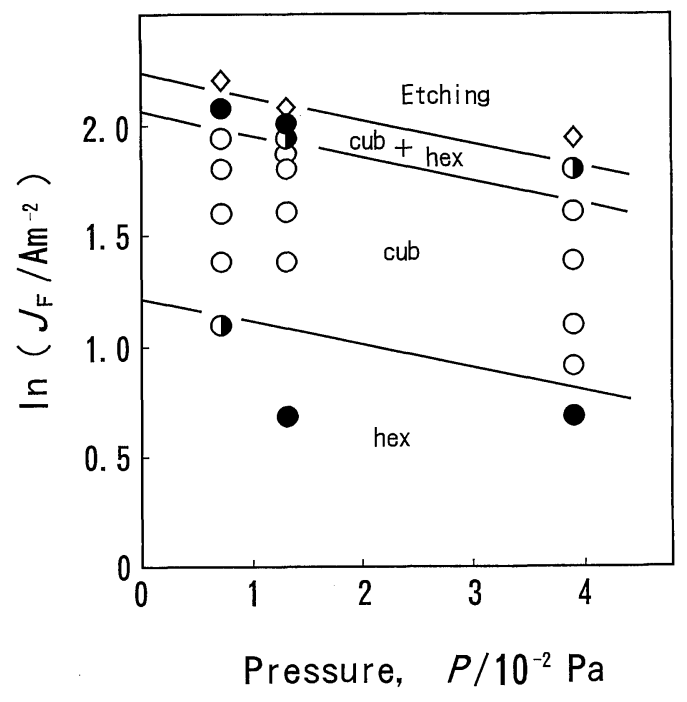

Fig. 8 Effects of operating pressure and current density on the phases of $\mathrm{BN}$ films. The gas composition was $\mathrm{Ar}+36 \% \mathrm{~N}_{2}$.

て, この条件範囲のシフトは荷電変換によるものと考学られ る.つまり，イオン源から引き出されたイオンの一部は，基板 まで輸送される間に真空槽内の熱運動している中性の粒子と荷 電変換し, 高速中性粒子となり基板に入射するが，この高速中 性粒子もイオンと同様に各相の生成に寄与するものと考えられ る.

そこで，ファラデーカップによる電流密度の測定では，イオ ン電流密度つまりイオン流束 $(\mathrm{i} F)$ しか計測できないため, 次の と掠り, イオン流束 $\left({ }^{\mathrm{i}} F\right)$ と高速中性粒子流束 $\left({ }^{\mathrm{n}} F\right)$ の和, つま り高速粒子流束 $\left({ }^{\mathrm{f}} F\right)$ を見積もった。 なお，イオンビームは空 間電荷効果により, イオン源を出てから発散するため, ここで はイオンビームの広がりは考えず, 基板位置で真空槽内圧力 $=0$ の時に測定される電流密度 $J_{0}$ のイオンビームが大口径の イオン源から基板の表面に向って垂直に照射されるものと仮定 した.

$$
\begin{gathered}
{ }^{\mathrm{f}} F={ }^{\mathrm{i}} F+{ }^{\mathrm{n}} F \fallingdotseq{ }^{\mathrm{i}} F_{0} \\
{\left[\begin{array}{ll}
{ }^{\mathrm{i}} F: \text { 基板位置でのイオン流束 } & {\left[\mathrm{m}^{-2} \mathrm{~s}^{-1}\right]} \\
{ }^{\mathrm{n}} F: \text { 基板位置での高速中性粒子流束 }\left[\mathrm{m}^{-2} \mathrm{~s}^{-1}\right] \\
{ }^{\mathrm{f}} F: \text { 基板位置での高速粒子流束 } & {\left[\mathrm{m}^{-2} \mathrm{~s}^{-1}\right]} \\
{ }^{\mathrm{i}} F_{0}: l=0 \text { の位置でのイオン流束 } & {\left[\mathrm{m}^{-2} \mathrm{~s}^{-1}\right]}
\end{array}\right]}
\end{gathered}
$$

基板位置のファラデーカップで測定されるイオン流束 $\left({ }^{\mathrm{i}} F\right)$ は 次式で表される(15).

$\left[\begin{array}{ll}\sigma_{\mathrm{e}}: \text { 荷電変換断面積 } & {\left[\mathrm{m}^{2}\right]} \\ P: \text { 基板 } ・ \text { イオン源間の圧力 } & {[\mathrm{Pa}]} \\ k_{\mathrm{B}}: \text { Boltzman 気体定数 } & {\left[\mathrm{Pa} \cdot \mathrm{m}^{3} \mathrm{~K}^{-1}\right]} \\ T: \text { 温度 } & {[\mathrm{K}]} \\ l: \text { 基板 } ・ \text { イオン源間距離 } & {[\mathrm{m}]} \\ e: \text { 電子の電荷 } & {[\mathrm{C}]} \\ J_{\mathrm{F}}: \text { 基板位置でのイオン電流密度 } & {\left[\mathrm{Am}^{-2}\right]} \\ J_{0}: l=0 \text { の位置でのイオン電流密度 }\left[\mathrm{Am}^{-2}\right]\end{array}\right]$

よって

$$
J_{\mathrm{F}}=J_{0} \exp \left[-\left(\sigma_{\mathrm{e}} P / k_{\mathrm{B}} T\right) \cdot l\right]
$$

Fig. 8 の傾きより $\sigma_{\mathrm{e}}=22 \times 10^{-20}\left[\mathrm{~m}^{2}\right]$ となり, Hubler ら ${ }^{(16)}$ の求めた $24 \times 10^{-20}\left[\mathrm{~m}^{2}\right]$, Flannery ら(17) の $27 \times 10^{-20}\left[\mathrm{~m}^{2}\right]$, Robinson ら ${ }^{(18)} の 22 \times 10^{-20}\left[\mathrm{~m}^{2}\right]$ とほぼ一致する.

これより，基板に入射する高速粒子流束を見積もることがで きる。な招，本試験では $\mathrm{Ar}$ と $\mathrm{N}_{2}$ の混合ガスを用いて招り， 厳密には各ガス組成により $\sigma_{\mathrm{e}}$ は異なり，また $\mathrm{Ar} イ オ ン と ~ \mathrm{~N}_{2}$ イオンの荷電変換する割合が異なる可能性があり精度向上のた めには，これらの計測が必要である.

\section{2. イオン電流密度およびイオン源への供給ガス組成の影響}

Fig. 6(a)の結果について，基板に入射する高速窒素流束お よび高速アルゴン流束に着目して以下のと招り考察を加えた.

まず， N-1 項で検討した真空槽内圧力の影響を考慮し， Fig. 6(a)のデータをプロットすると Fig. 9 となる.

ここで縱軸は基板に入射するイオン流束 $(\mathrm{i} F)$ 之高速中性粒子 流束 $\left({ }^{\mathrm{n}} F\right)$ の和, つまり高速粒子流束 $\left({ }^{\mathrm{f}} F\right)$ である. カウフマン 型イオン源から供給されるイオンは一価のイオンが大部分であ る(19)から，

\begin{tabular}{|c|c|c|c|c|}
\hline $\begin{array}{c}\text { Pressure } \\
\mathrm{Pa}\end{array}$ & $c-B N$ & $\begin{array}{r}\quad-B N \\
+h-B N \\
\end{array}$ & $h-B N$ & Etching \\
\hline $6.7 \times 10^{-3}$ & $\square$ & 口 & घ & \multirow{3}{*}{$\diamond$} \\
\hline $1.3 \times 10^{-2}$ & 0 & (1 & - & \\
\hline $4.0 \times 10^{-2}$ & $\triangle$ & $\boldsymbol{\Lambda}$ & $\Delta$ & \\
\hline
\end{tabular}

$$
\begin{aligned}
& { }^{\mathrm{f}} F \fallingdotseq{ }^{\mathrm{f}} F_{\mathrm{Ar}}+{ }^{\mathrm{f}} F_{\mathrm{N}_{2}}+{ }^{\mathrm{f}} F_{\mathrm{N}} \\
& \left.={ }^{\mathrm{f}} F_{\mathrm{Ar}}+(1+k)\right)^{\mathrm{f}} F_{\mathrm{N} 2} \quad\left(k={ }^{\mathrm{f}} F_{\mathrm{N}} /{ }^{\mathrm{f}} F_{\mathrm{N}_{2}}\right) \\
& {\left[\begin{array}{l}
{ }^{\mathrm{f}} F_{\mathrm{Ar}}: \text { 高速 } \mathrm{Ar} \text { 流束 } \\
{ }^{\mathrm{f}} F_{\mathrm{N}}: \text { 高速 } \mathrm{N} \text { 流束 } \\
{ }^{\mathrm{f}} F_{\mathrm{N}_{2}}: \text { 高速 } \mathrm{N}_{2} \text { 流束 }
\end{array}\right]}
\end{aligned}
$$

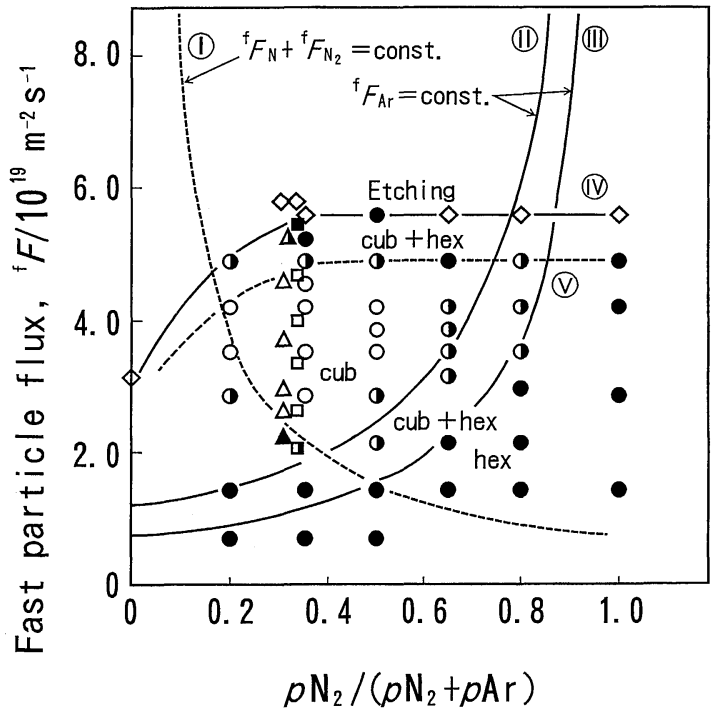

Fig. 9 Effects of $p \mathrm{~N}_{2} /\left(p \mathrm{~N}_{2}+p \mathrm{Ar}\right)$ and fast particle flux on the phases of $\mathrm{BN}$ films. 
${ }^{\mathrm{f}} F_{\mathrm{Ar}}$ と $x$ の関係は単調増加, $(1+k) \mathrm{f} F_{\mathrm{N}_{2}}$ と $x$ の関係は単調減少 で,

$$
\begin{gathered}
{ }^{\mathrm{f}} F_{\mathrm{Ar}} /{ }^{\mathrm{f}} F=(1-x) g(x) \\
(1+k)^{\mathrm{f}} F_{\mathrm{N}_{2}} /{ }^{\mathrm{f}} F=x g(x) \\
{\left[\begin{array}{l}
x \quad \text { イオン源への供給ガス組成 } \quad\left(=\frac{p_{\mathrm{N}_{2}}}{p_{\mathrm{Ar}_{\mathrm{r}}}+p_{\mathrm{N}_{2}}}\right) \\
g(x): \text { イオン源への供給ガス組成と得られるイオ } \\
\text { ソの比率の補正関数 } \\
g(0)= \\
g(1)=1, g^{\prime}(x) \geqq 0, g(x)>0
\end{array}\right]}
\end{gathered}
$$

曲線 (I) は $g(x)=1$ とした場合の $(1+k)^{\mathrm{f}} F_{\mathrm{N}_{2}}=7.5 \times 10^{18}$ $\mathrm{m}^{-2} \mathrm{~s}^{-1}$ の等高速窒素流束線で, 式 $(6)$ より $\mathrm{f} F=7.5 \times 10^{18} / x$ で表される.cBNは，この線の右側で形成され，ほう素が窒 化するためには一定以上の高速窒素流束が必要であることを示 している.この線の左ではXPS の結果よりほう素が過剩であ るのは Fig. 7 に示したと物りである.な拈， $p_{\mathrm{N}_{2}}=1$, 放電電圧 $30 \sim 60 \mathrm{~V}$ の時, $k=0.07 \sim 0.3$ であるが(19), $k=0.3$ としても曲 線(I)の $(1+k)^{\mathrm{f}} F_{\mathrm{N}_{2}}$ による窒素原子の供給速度は $F_{\mathrm{N}}=1.3 \times 10^{19}$ $\mathrm{m}^{-2} \mathrm{~s}^{-1}$ であり, $F_{\mathrm{N}} / F_{\mathrm{B}}=2.0>1$ である.よって, cBN 形成 のためには医ら素に対して過唾の窒素を供給する必要がある か，もしくは， $F_{\mathrm{N}} / F_{\mathrm{B}}=1$ で十分であるなら，本試験条件では $g(x)<1$ となっているるのと推定される.

また, 曲線 (II), (III) $g(x)=1$ とした場合の ${ }^{\mathrm{f}} F_{\mathrm{Ar}}=1.2 \times 10^{19}$ $\mathrm{m}^{-2} \mathrm{~s}^{-1}, 7.5 \times 10^{18} \mathrm{~m}^{-2} \mathrm{~s}^{-1}$ の等高速アルゴン流束線で, 式 $(5$ ) より ${ }^{\mathrm{f}} F=1.2 \times 10^{19} /(1-x)$ と ${ }^{\mathrm{f}} F=7.5 \times 10^{18} /(1-x)$ で表される. $\mathrm{cBN}$ は曲線の左側で形成され, 高速アルゴン流束が一定以 上必要であることを示している.曲線から右側の方向に条件 が変わるにしたがって，つまり高速アルゴン流束が不足すると， $\mathrm{hBN}$ が混在し(曲線(II) (III)間), さらに不足すると $\mathrm{hBN}$ しか 生成しないことを示している.

また曲線田はェッチング境界線で, 基板に入射する高速粒子 流束が注う素供給速度つまり注ら素流束に対して過剩であるた め皮膜が形成されずェッチングされる.

曲線 (N)とのあいだの $\mathrm{cBN}$ 相と $\mathrm{hBN}$ 相の混在領域の生成 はェッチング領域に近いことより，次の 2 点に起因するもの と推定される.

(1)過剩なイオン照射により完全な $\mathrm{cBN}$ の構造をとりえない 条件範囲である.あるいは, (2)皮膜が薄いため, 基板と皮膜界 面での不整合相执よび $\mathrm{Si}$ 基板から $\mathrm{Si}$ がスパッタされ皮膜に混 入した界面相の赤外吸収を含んでいる.

\section{V. 結 論}

注う素の電子ビーム蒸着と窒素, アルゴン混合イオン照射を 併用した IVD 法により， $\mathrm{Si}$ 基板上に $\mathrm{BN}$ 皮膜を作製し，cBN 生成条件範囲に及ぼすイオン電流密度, イオン源への供給ガス 組成, 真空槽内圧力の影響について検討し, 以下の結果を得 た.

（1）注う素供給速度一定の場合, 適正なイオン電流密度範囲 で $\mathrm{cBN}$ が生成した.
（2）イオン加速電圧 $0.5 \mathrm{kV}$, 注う素供給速度 $0.13 \mathrm{nms}^{-1}$ で 一定の場合. $\mathrm{Ar}+20 \sim 80 \% \mathrm{~N}_{2}$ の混合ガスをイオン源に導入す ることにより $\mathrm{cBN}$ が生成した. この中で $\mathrm{cBN}$ の成膜速度が大 きく, cBN の生成条件範用が広いガス組成は $\mathrm{Ar}+36 \sim 50 \% \mathrm{~N}_{2}$ であった.

（3）真空槽内圧力の増加により，各 $\mathrm{BN}$ 相の生成条件範囲 は低イオン電流密度側にシフトした. これは荷電変換によるも のと考觉られ，イオンのみならず，加速された高速中性粒子も cBN の生成に寄与するものと推定される.

（4）以上の結果をもとに，cBN 生成条件範囲を高速窒素流 束, 高速アルゴン流束で整理した $\mathrm{cBN}$ 生成条件マップを提案 し, cBN 生成にはほら素供給速度に対して一定值以上の高速 窒素流束执よび高速アルゴン流束が必要であることを示した。

(5) 得られた $\mathrm{cBN}$ 膜は, XPS よりほぼ化学量論的組成を示 し, 電子線回折より $\mathrm{cBN}(111),(220),(311)$ 面飞相当する回 折線が観測された.

\section{文献}

(1) O. Misima, J. Tanaka, S. Yamaoka and O. Fukunaga: Science, 238(1987), 181.

(2 ) C. Weissmantel, K. Bemlogua, D. Dietrich, H. J. Erler, H. J. Hinnebrg, S. Klose, W. Nowick and G. Reisse: Thin Solid Films, 72 (1980), 19.

( 3 ) T. Satou and F. Fujimoto: Jpn. J. Appl. Phys., 22 (1983), 171.

(4) K. Inagawa, K. Watanabe, I. Tanaka, K. Saitoh and A. Itoh: Proc. 9th Symp. on ISIAT., The Ion Engineering Society of Japan, (1985), 381.

( 5 ) M. Mieno and T. Yoshida: Jpn. J. Appl. Phys., 29 (1990), 1175.

(6) T. Mohri, O. Iijima and Y. Nanba: J. Vac. Soc. Jpn., 29(1986), 404

( 7 ) S. Komatu, T. Yoshida and K. Akashi: Proc. 9th Symp. on ISIAT., The Ion Engineering Society of Japan, (1985), 421.

( 8 ) Y. Ichinose, H. Saitoh and T. Ichiguro: Proc. 9th Symp. on ISIAT., The Ion Engineering Society of Japan, (1987), 469.

( 9 ) A. Chayahara, H. Yokoyama, T. Imura and Y. Osaka: Jpn. J. Appl. Phys., 26(1987), 1435.

(10) N. Yamashita and T. Wada: J. Vac. Sci. Technol., A10 (1992), 515

(11) N. Yamashita, T. Wada, M. Ogawa, T. Kobayashi, H. Tsukamoto and T. Rokkaku: Surface and Coating Technol., 54/55(1992), 418.

(12) M. Sueda, T. Kobayasi, H. Tsukamoto, T. Rokkaku, S. Morimoto, Y. Fukaya, N. Yamashita and T. Wada: Thin Solid Films, 228(1993), 97.

(13) P. J. Gielisse, S. S. Mitra, J. N. Plendl, R. D. Griffis, L. C. Mansur, R. Marshall and E. A. Pascoe: Phys. Rev., 115 (1967), 1039.

(14) R. Geick and C. H. Perry: Phys. Rev., 146(1966), 543.

(15) 石川順三 : イオン源工学, アイオニクス(侏), (1986), 49.

(16) G. K. Hubler, D. Van Vechten and EP. Donovan: J. Vac. Technol., A8(1990), 831.

(17) M. R. Flannery, P. C. Cosby and T. F. Moran: J. Chem Phys., 59(1973), 5494.

(18) R. S. Robinson: J. Vac. Sci. Technol., 16(1979), 185.

(19) D. Van Vechten, G. K. Hubler and E. P. Donovan: Vacuum, 36(1986), 841. 